\title{
The effect of implantation materials based on equine and bovine xenogenic bone extracellular matrix on the formation of extracellular neutrophilic traps (experimental study)
}

\author{
O.V. Diuriagina ${ }^{1}$, M.V. Chepeleva ${ }^{1}$, E.I. Kuznetsova ${ }^{1}$, M.A. Kovinka ${ }^{1}$, A.N. Nakoskin ${ }^{2}$ \\ ${ }^{1}$ Ilizarov National Medical Research Centre for Traumatology and Orthopedics, Kurgan, Russian Federation \\ ${ }^{2}$ Kurgan State University, Kurgan, Russian Federation
}

\begin{abstract}
Purpose To study the effect of osteoplastic materials based on the extracellular xenomatrix of bovine and equine bone tissue on the formation of neutrophil extracellular traps (NETs) in the peripheral blood of rabbits in the early post-operative period after implantation. Materials and methods The study was carried out on 18 male rabbits of the Soviet Chinchilla breed, aged from 8 months to 1.2 years, weighing from 3.0 to $4.5 \mathrm{~kg}$. A perforated bone defect of a cylindrical shape measuring $2 \times 6 \mathrm{~mm}$ in the distal metaphysis of the right and left femurs was modeled in the animals. The rabbits were divided into three groups, six animals each. In group I, the bone defect was left unfilled; in group II, the defect was filled with a bovine bone tissue xenomatrix, and an equine bone tissue xenomatrix was implanted in group III animals. The implantation material had the appearance of a yellowish crumb with a particle size of 0.5-1 mm. Blood smears stained according to Romanovsky-Giemsa were used for counting extracellular neutrophil traps (NETs). The percentage of neutrophils that passed the stages of nuclear transformation and emitted free chromatin into the extracellular space in the form of network-like structures was calculated. Results On days 3-7 of the experiment, the number of NETs increased in the early stages of NETosis in all groups. There were no significant differences between the groups. In group I, on days 7 and 14, the number of early forms of NETs (stages 1a and 1b) returned to the values of the preoperative period. In groups II and III, normalization of NETs (stage 1a) did not occur, and the content of NETs (stage 1b) returned to the initial level only by day 30 of the experiment. On days $3,7,14$, the number of mature NETs increased in all groups. The highest values were noted in group II, where the bovine xenogeneic matrix was implanted. Conclusion Implantation materials based on the extracellular matrix of equine and bovine xenogeneic bone stimulate excessive formation of early NETs on days 14-30 of the experimental period in response to xenotransplantation. Xenomaterials of bovine bone tissue, in comparison with xenomaterials of equine bone tissue, induce a more pronounced inflammatory reaction in the nearest time after defect filling, which is manifested by higher production of mature NETs on days 3-14 of the experiment.
\end{abstract}

Keywords: neutrophil extracellular traps (NETs), bone defect, xenomatrix of bovine bone tissue, xenomatrix of equine bone tissue

\section{INTRODUCTION}

Bone defects resulting from injuries, diseases, surgical interventions or congenital disorders remain challenging problems in contemporary orthopaedics and traumatology [1].

There is an extremely high demand for bone grafts currently. The use of autologous bone is limited due to the complexity of obtaining large volumes of bone material and additional invasiveness during the collection of bone tissue [2]. An alternative to autoplasty is the use of xenomaterials from bone tissue, which, in turn, contain foreign antigens in their structure. It can cause biological incompatibility, leading to the development of an immune cell-mediated rejection, an acute humoral response, initially mediated by the formation of IgM antibodies, mainly to the gal epitope, with a subsequent increase in the level of IgG, overproduction of cytokines $[3,4]$. The complex interactions between inflammation, coagulation and the immune response are well known [5]. At the same time, the role of inflammation has not been fully understood if bone tissue xenomatrix is applied. Therefore, the study of immunological parameters may be used to assess the course of the postoperative period after implantation xenomaterials from bone tissue and the "survival" of the implant.

The aim of the study was to investigate the effect of bone plastic materials based on extracellular xenomatrix of bovine and equine bone tissue on the formation of extracellular neutrophil traps (NETs) in the peripheral blood of rabbits in the early postoperative period after their implantation.

\section{MATERIAL AND METHODS}

The experimentd was carried out on 18 male rabbits of the Soviet Chinchilla breed, aged from 8 months to 1.2 years, weighing from 3.0 to $4.5 \mathrm{~kg}$. A non-through bone defect of a cylindrical shape measuring $2 \times 6 \mathrm{~mm}$ in the distal metaphysis of the right and left femur was modeled in the animals. The rabbits were divided into three groups of 6 animals each. In group I (control), the bone defect was left unfilled, in group II, the defect was filled with a bovine bone tissue xenomatrix, and equine bone 
tissue xenomatrix was implanted in group III animals. The implantation material had the appearance of a yellowish crumb with a particle size of $0.5-1 \mathrm{~mm}$. Xenogenic implantation materials were produced from the bovine and equine cancellous bone using one and the same technology [6].

Maintanence of the animals and manipulations were performed in compliance with the principles of humane treatment of laboratory animals in accordance with the requirements of regulatory documents and the European Convention for the Protection of Vertebrate Animals Used for Experiments or Other Scientific Purposes, and Directive 2010/63 / EU of the European Parliament and the Council of the European Union on protection of animals used for scientific purposes $[7-9,10]$. The study was approved by the local ethical committee (protocol No. 2/57 dated 05.17.2018).

Blood samples were collected from the animals of all groups from the marginal ear vein at the following time points: before implantation, on days 7, 14 and 30 of the experiment.

Neutrophilic extracellular traps (NETs) were counted in blood smears stained according to Romanovsky-Giemsa. The percentage of neutrophils that passed the stages of nuclear transformation and released free chromatin into the extracellular space as network-like structures was calculated. The NETs were counted using an Axio Lab.A 1 light microscope (Karl Zeiss MicroImaging GmbH; objective 100 (MI), eyepiece $12.5 \mathrm{x}$ ) using immersion.

The AtteStat software which is a Microsoft Excel application was used for statistical. The research results are presented as median, first, third quartiles. To identify group differences at each stage of the study, statistical analysis of multiple comparisons was performed using the Kruskal-Wallis test. To accept or reject the null hypothesis, the initial level of $\alpha$ was taken equal to 0.05 . If there was a difference between the study groups (the null hypothesis was rejected), then additionally, using a posteriori pairwise comparisons with the MannWhitney test, it was determined between which groups there were significant differences (I-II, I-III, II-III). The statistical significance of post hoc comparisons (for $\mathrm{p}<0.05$ ), taking into account the number of groups (3), was accepted as $0.05 / 3=0.0167$. In addition, using the Kruskal-Wallis test, significant differences were found between the period before the operation $(\mathrm{b} / \mathrm{o})$ and each of the subsequent stages of the study (days $3,7,14,30$ ) in each of the groups. In this case, the statistical significance of paired comparisons, taking into account the number of groups (5), was taken as $0.05 / 5=0.010$.

\section{RESULTS}

The general condition of the rabbits in all series of the experiment was satisfactory on the first three postoperative days. The animals moved little, sparing their limbs. There was a slight increase in their body temperature (by $0.2-0.3{ }^{\circ} \mathrm{C}$ ), decreased appetite and weight loss from 100 to 350 grams. From days 5-6 onwards, the general condition of the animals and their appetite improved, the functions of the organs and systems returned to normal. The rabbits moved freely in the cage and stood on the hind limbs. They also gained 150 to 380 gr of body weight.

Status localis On the first day after the operation, a moderate postoperative soft-tissue edema in the areas of surgical interventions developed. Tenderness of soft tissues was insignificant. There was an abundant discharge of serous exudate from the surgical wounds. By the seventh day, these symptoms disappeared, the suture line was covered with a 2-mm dry scab. The surgical wounds in all animals healed after 10-11 post-operative days.

In the later time points of the experiment, the skin in the implantation zones was smooth, mobile, elastic, post-operative scars were pale and threadlike. Soreness, swelling or deformities of the knee joint were not observed.

Before the operation, there were no significant differences in the number of neutrophil traps between the groups (Tables 1, 2,3). The response to surgery in all groups was activation of NETosis. In comparison with the preoperative values, the content of both early and mature neutrophil traps increased. On days 3 and 7 of the experiment, the number of NETs in their early stages increased in all groups ( $1 \mathrm{a}$ and $1 \mathrm{~b})$. There were no significant differences between the groups. In group I, on days 7 and 14, the number of early forms of NETs (stages 1a and $1 \mathrm{~b}$, respectively) returned to preoperative values. In groups II and III, the content of immature NETs (stage 1a) did not normalize in the post-operative period, and the number of NETs in stage $1 \mathrm{~b}$ returned to the initial level only by the 30 th day of the experiment.

The development of mature neutrophil traps looked somewhat different. On days 3, 7, 14, the relative number of NETs increased in all groups. Significant differences were found between groups I and II. The highest values were revealed in the group with the implantation of the bovine xenosis matrix. By day 30 of the experiment, a decrease in the number of mature NETs was observed in all groups; there were no significant differences between the groups. Thereby, by that time point the indicator reached preoperative values in groups I and III, and exceeded the initial level in group II. 
Table 1

Number of early NETs (stage 1a)

\begin{tabular}{|c|c|c|c|c|c|}
\hline \multicolumn{2}{|c|}{ Study period } & Group I & Group II & Group III & $\begin{array}{c}\text { Kruskal-Wallis test } \\
\text { (differences between the } \\
\text { groups) }\end{array}$ \\
\hline \multirow{2}{*}{ Before operation } & $\%$ & $3.5(3.0-4.0)$ & $3.5(3.0-4.75)$ & $3.5(3.0-4.7)$ & $\mathrm{p}>0.05$ \\
\hline & $10^{9} / 1$ & $0.1(0.075-0.15)$ & $0.09(0.07-0.16)$ & $0.1(0.072-0.16)$ & $\mathrm{p}>0.05$ \\
\hline \multirow{2}{*}{ Day 3} & $\%$ & $5,5(5,0-6,75)$ & $6,0(5,0-7,0)$ & $6,0(5,25-6,0)$ & $p>0.05$ \\
\hline & $10^{9} / 1$ & $0.18(0.14-0.21)$ & $0.23(0.16-0.26)$ & $0.22(0.15-0.25)$ & $p>0.05$ \\
\hline \multirow{2}{*}{ Day 7} & $\%$ & $4.0(3.25-7.25)$ & $6.0(5.25-6.75)$ & $5.0(5.0-7.25)$ & $p>0.05$ \\
\hline & $10^{9} / 1$ & $0.15(0.11-0.2)$ & $0.2(0.15-0.22)$ & $0.17(0.17-0.2)$ & $p>0.05$ \\
\hline \multirow{2}{*}{ Day 14} & $\%$ & $2.5(2.0-3.5)$ & $7.5(7.0-8.75)$ & $7.0(6.25-7.75)$ & $\begin{array}{l}\mathrm{H}=11.17, p=0.0038 \\
\text { I-II: } p=\mathbf{0 . 0 0 3 9} \\
\text { I-III: } p=\mathbf{0 . 0 0 3 7}\end{array}$ \\
\hline & $10^{9} / 1$ & $0.068(0.055-0.082)$ & $0.21(0.19-0.3)$ & $0.24(0.22-0.26)$ & $\begin{array}{l}\mathrm{H}=10.98, p=0.008 \\
\text { I-II: } p=0.0044 ; \\
\text { I-III: } p=\mathbf{0 . 0 0 3 8}\end{array}$ \\
\hline \multirow[t]{2}{*}{ Day 30} & $\%$ & $3.5(3.0-4.75)$ & $7.5(6.25-8.0)$ & $8.0(7.25-8.75)$ & $\begin{array}{l}\text { HH }=8.7, p=0.013 \\
\text { I-II: } p=0.012 ; \\
\text { I-III: } p=0.008\end{array}$ \\
\hline & $10^{9} / 1$ & $0.1(0.088-0.139)$ & $0.176(0.146-0.188)$ & $0.22(0.17-0.31)$ & $\begin{array}{l}H=9.2, p=0.02 \\
\text { I-III: } p=0.011\end{array}$ \\
\hline \multicolumn{2}{|c|}{$\begin{array}{l}\text { Kruskal-Wallis test (differences } \\
\text { between the period before operation } \\
\text { and subsequent terms, \%) }\end{array}$} & $\begin{array}{l}H=10.32, p=0.035 \\
b / 0-3 \text { days: } p=0.008\end{array}$ & $\begin{array}{l}\mathrm{H}=11.64, \mathrm{p}=\mathbf{0 . 0 2} \\
\text { b/o-3 days: } \mathrm{p}=\mathbf{0 . 0 0 8} \\
\text { b/o-7 days: } \mathrm{p}=\mathbf{0 . 0 1 0} \\
\text { b/o-14 days: } \mathrm{p}=\mathbf{0 . 0 0 2} \\
\text { b/o-30 days: } \mathrm{p}=\mathbf{0 . 0 0 7}\end{array}$ & $\begin{array}{l}\mathrm{H}=11.3, \mathrm{p}=\mathbf{0 . 0 2 5} \\
\text { b/o-3 days: } \mathrm{p}=\mathbf{0 . 0 0 8 6} \\
\text { b/o-7 days: } \mathrm{p}=\mathbf{0 . 0 1 0} \\
\text { b/o-14 days: } \mathrm{p}=\mathbf{0 . 0 1 0} \\
\text { b/o-30 days: } \mathrm{p}=\mathbf{0 . 0 0 4}\end{array}$ & \\
\hline
\end{tabular}

Table 2

Number of early NETs (stage 1b)

\begin{tabular}{|c|c|c|c|c|c|}
\hline \multicolumn{2}{|c|}{ Study period } & \multirow{2}{*}{$\begin{array}{c}\text { Group I } \\
2.5(2.0-3.0)\end{array}$} & \multirow{2}{*}{$\begin{array}{c}\text { Group II } \\
2.0(0.5-2.75)\end{array}$} & \multirow{2}{*}{$\begin{array}{c}\text { Group III } \\
2.5(2.0-3.0)\end{array}$} & \multirow{2}{*}{$\begin{array}{c}\text { Kruskal-Wallis test } \\
\text { (differences between the } \\
\text { groups) }\end{array}$} \\
\hline & $\%$ & & & & \\
\hline Before operation & $10^{9} / 1$ & $0.075(0.06-0.085)$ & $0.051(0.02-0.07)$ & $0.073(0.05-0.084)$ & $p>0.05$ \\
\hline \multirow{2}{*}{ Day 3} & $\%$ & $5.0(4.0-6.0)$ & $8.5(5.75-9.75)$ & $4.5(3.25-5.75)$ & $p>0.05$ \\
\hline & $10^{9} / 1$ & $0.166(0.14-0.198)$ & $0.33(0.23-0.38)$ & $0.17(0.13-0.22)$ & $p>0.05$ \\
\hline \multirow{2}{*}{ Day 7} & $\%$ & $4.5(4.0-7.25)$ & $6.0(5.25-7.5)$ & $6.5(6.0-8.5)$ & $p>0.05$ \\
\hline & $10^{9} / 1$ & $0.17(0.15-0.21)$ & $0.2(0.15-0.22)$ & $0.2(0.16-0.22)$ & $p>0.05$ \\
\hline \multirow{2}{*}{ Day 14} & $\%$ & $3.5(2.25-4.75)$ & $6.0(4.25-10.0)$ & $4.5(4.0-5.0)$ & $p>0.05$ \\
\hline & $10^{9} / 1$ & $0.1(0.06-0.13)$ & $0.16(0.14-0.18)$ & $0.14(0.11-0.15)$ & $p>0.05$ \\
\hline \multirow{2}{*}{ Day 30} & $\%$ & $2.0(1.25-2.0)$ & $2.5(2.0-3.0)$ & $2.5(2.0-3.0)$ & $p>0.05$ \\
\hline & $10^{9} / 1$ & $0.06(0.045-0.06)$ & $0.065(0.05-0.085)$ & $0.08(0.07-0.085)$ & $p>0.05$ \\
\hline \multicolumn{2}{|c|}{$\begin{array}{l}\text { Kruskal-Wallis test (differences } \\
\text { between the period before operation } \\
\text { and subsequent terms, \%) }\end{array}$} & $\begin{array}{l}\mathrm{H}=17.15, p=0.0018 \\
\text { b/o-3 days: } p=0.004 \\
\text { b/o-7 days: } p=0.004\end{array}$ & $\begin{array}{l}H=17.39, p=0.0016 \\
\text { b/o-3days: } p=0.003 \\
\text { b/o-7 days: } p=0.0019 \\
\text { b/o-14 days: } p=0.008\end{array}$ & $\begin{array}{l}H=17.86, p=0.0013 \\
\text { b/o-3days: } p=0.008 \\
\text { b/o-7 days: } p=0.0019 \\
\text { b/o-14 days: } p=0.002\end{array}$ & \\
\hline
\end{tabular}

Table 3

Number of mature NETs

\begin{tabular}{|c|c|c|c|c|c|}
\hline \multicolumn{2}{|c|}{ Study period } & \multirow{2}{*}{$\begin{array}{c}\text { Group I } \\
1.0(0.25-1.0)\end{array}$} & \multirow{2}{*}{$\begin{array}{c}\text { Group II } \\
0.5(0.0-1.0)\end{array}$} & \multirow{2}{*}{$\begin{array}{c}\text { Group III } \\
0.5(0.0-1.0)\end{array}$} & \multirow{2}{*}{$\begin{array}{c}\text { Kruskal-Wallis test } \\
\text { (differences between the } \\
\text { groups) } \\
\mathrm{p}>0.05\end{array}$} \\
\hline & $\%$ & & & & \\
\hline Betore operation & $10^{9} / 1$ & $0.03(0.007-0.03)$ & $0.012(0.0-0.026)$ & $0.015(0.0-0.029)$ & $\mathrm{p}>0.05$ \\
\hline \multirow[t]{2}{*}{ Day 3} & $\%$ & $9.5(9.0-10.0)$ & $14.5(13.25-22.5)$ & $12.0(8.5-14.5)$ & $\begin{array}{l}H=6.1, p=0.04 \\
I-I I: p=0.010\end{array}$ \\
\hline & $10^{9} / 1$ & $0.31(0.3-0.33)$ & $0.35(0.3-0.5)$ & $0.4(0.3-0.054)$ & $\mathrm{p}>0.05$ \\
\hline \multirow[t]{2}{*}{ Day 7} & $\%$ & $7.5(6.25-8.75)$ & $11.0(9.25-14.25)$ & $7.5(6.25-8.75)$ & $\begin{array}{l}\mathrm{H}=9.8, p=0.075 \\
\text { I-II: } p=0.016\end{array}$ \\
\hline & $10^{9} / 1$ & $0.29(0.25-0.34)$ & $0.37(0.31-0.49)$ & $0.3(0.21-0.32)$ & $p>0.05$ \\
\hline \multirow{2}{*}{ Day 14} & $\%$ & $3.5(3.0-5.5)$ & $8.5(8.0-9.0)$ & $6.0(5.25-7.5)$ & $\begin{array}{l}H=8.05, p=0.018 \\
\text { I-II: } p=0.010\end{array}$ \\
\hline & $10^{9} / 1$ & $0.096(0.08-0.15)$ & $0.23(0.21-0.3)$ & $0.21(0.18-0.26)$ & $\begin{array}{l}\mathrm{H}=7.9, p=0.018 \\
\text { I-II: } p=0.016\end{array}$ \\
\hline \multirow{2}{*}{ Day 30} & $\%$ & $1.0(1.0-1.75)$ & $2.0(1.25-2.0)$ & $1.5(1.0-2.75)$ & $\mathrm{p}>0.05$ \\
\hline & $10^{9} / \mathbf{l}$ & $0.029(0.029-0.05)$ & $0.046(0.029-0.046)$ & $0.05(0.034-0.09)$ & $p>0.05$ \\
\hline \multicolumn{2}{|c|}{$\begin{array}{l}\text { Kruskal-Wallis test (differences } \\
\text { between the period before operation } \\
\text { and subsequent terms, \%) }\end{array}$} & $\begin{array}{l}H=25.8, p=0.0001 \\
\text { b/o-3 days: } p=0.0019 \\
\text { b/o-7 days: } p=0.002 \\
\text { b/o-14 days: } p=0.002\end{array}$ & $\begin{array}{l}\mathrm{H}=23.5, p=0.0001 \\
\text { b/o-3 days: } p=0.0019 \\
\text { b/o-7 days: } p=0.002 \\
\text { b/o-14 cyr: } p=\mathbf{0 . 0 0 2} \\
\text { b/o-30 days: } p=0.008\end{array}$ & $\begin{array}{l}\mathrm{H}=22.8, p=0.0001 \\
\text { b/o-3 days: } p=0.0011 \\
\text { b/o-7 days: } p=0.0011 \\
\text { b/o-14 days: } p=0.002\end{array}$ & \\
\hline
\end{tabular}




\section{DISCUSSION}

The course of the inflammatory process has a significant impact on the outcome of xenogenic material implantation. Analysis of literature sources showed that the following immunological parameters and tests were used to assess the immune response and inflammation activity in xenoimplantation: TNFa, TNF $\beta$, IFN- $\gamma$, IL-2, IL-4, IL-6, IL-10, TGF, IL- 12P70, IL-12, immunoglobulins, lymphocyte subpopulations, C-reactive protein, lymphocyte transformation test (LTT), memory lymphocyte immunostimulation assay (MELISA), leukocyte migration inhibition test (LIF), lymphocyte activation test (LAT) [11-15].

We did not find any data on the study of NETosis to assess the course of the post-operative period by implantation of xenografts for filling bone defects in the available literature. The probable reason may be the fact that the third protective strategy of neutrophils (formation of neutrophilic extracellular traps) was discovered quite recently (2004), and the study of NETosis processes in various pathological conditions and surgical interventions has been at the stage of data accumulation [16].

At the initial stage of NETosis (1a), individual vacuoles seen as light round spots were formed inside the neutrophil against the background of chromatin, which had a dense structure and was distributed over the entire inner surface of the cell. The cell wall remained dense; the cell volume increased by 1.5 2 times (Fig. 1). At the next stage (1b), chromatin occupied the entire inner surface of the cell and acquired a reticular structure. The mesh became threadlike and thinned; vacuoles were no longer visible. The cell lost its rounded shape, the neutrophil membrane became thinner and its thickness became uneven, protrusions appeared on the surface of the membrane. However, the release of DNA fibers did not occur at this stage of NETosis. At the stage of the mature trap, chromatin along with highly active antimicrobial proteins and enzymes, was released into the extracellular space as a mesh [17].
In group I (defect without filling), the changes reflected a direct response to the surgical intervention. In groups II and III, a combined response to surgical trauma and implanted bone tissue xenomatrix was observed. According to the data obtained, activation of NETosis in response to xenoimplantation was noted in all groups. In group I without implantation, the production of early neutrophil extracellular traps returned to the preoperative level by 14 days, mature ones by 30 days of the experiment. In the groups where the materials based on the equine and bovine extracellular bone matrix were used, the number of mature NETs was also normalized by 30 days of the post-operative period and indicated the absence of an active inflammatory process in the implantation zone at this stage. At the same time, the increased formation of early neutrophil traps continued. Earlier, we presented the data that not only bacterial agents but also non-microbial factors were able to stimulate NETtosis. In this case, neutrophil traps remain at the stage of nuclear transformation, the release of DNA network does not occur [18]. Consequently, the xenomatrix of the equine or bovine bone tissue was perceived by the rabbit's body as a foreign substance and had a slight stimulating effect.

It is known that the xenomatrix of the bovine bone tissue undergoes resorption and organotypic rearrangement faster than the equine xenomatrix [19]. It might be assumed that it is associated with the development of a more pronounced inflammatory response to the implantation of the bovine bone matrix than to the equine material, to which the body reacts more inertly.

Thus, xenogenic material implantation leaves a large field for research and contains a number of unsolved problems. The search for the ways to ensure safe and effective integration of xenogenic bone materials would deepen the understanding of the mechanisms of postoperative complications and develop ways to improve treatment results.

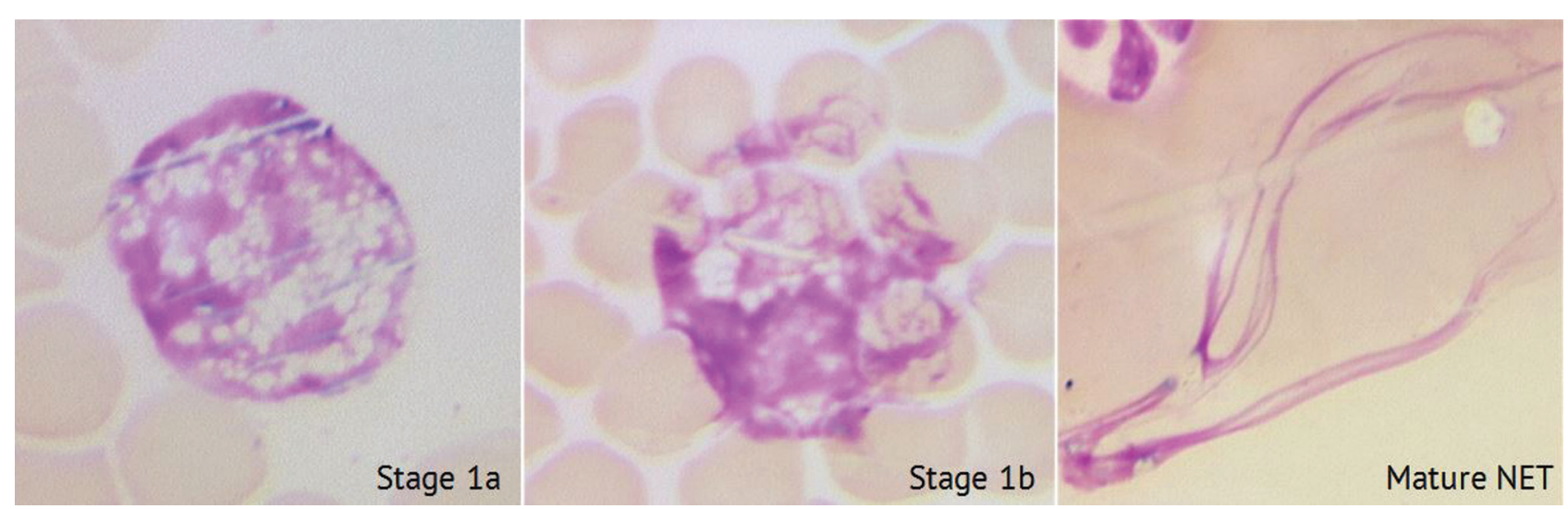

Fig. 1 Stage of neutrophil extracellular trap (NET) 


\section{CONCLUSION}

Implantation materials based on the extracellular matrix of equine and bovine xenogenic bone stimulate excessive formation of early NETs on days 14 to 30 of the experimental period in response to xenotransplantation, in contrast to the control group where the number of early NETs was normalized on day 14 (at the stage of wound healing).
Xenomaterials based on bovine bone tissue, in comparison with xenomaterials based on equine bone tissue, cause a more pronounced inflammatory response in the immediate term after defect filling, which is manifested by the highest production of mature NETs on days 3 to 14 of the experiment.

\section{REFERENCES}

1. Lekishvili M.V., Sklianchuk E.D., Akatov V.S., Ochkurenko A.A., Gurev V.V., Raginov I.S., Bugrov S.N., Riabov A.Iu., Fadeeva I.S., Iurasova Iu.B., Chekanov A.S. Kostnoplasticheskie osteoinduktivnye materialy v travmatologii i ortopedii [Osteoplastic osteoinductive materials in traumatology and orthopaedics]. Genij Ortopedii, 2015, no. 4, pp. 62-67. (in Russian)

2. Haugen H.J., Lyngstadaas S.P., Rossi F., Perale G. Bone grafts: which is the ideal biomaterial? J. Clin. Periodontol., 2019, vol. 46, no. Suppl. 21, pp. 92-102. DOI: $10.1111 /$ jcpe. 13058

3. Bokov A.E., Mliavykh S.G., Shirokova N.Iu., Davydenko D.V., Orlinskaia N.Iu. Sovremennye perspektivy razrabotki materialov dlia stabiliziruiushchikh vmeshatelstv na pozvonochnike s primeneniem spondilodeza (obzor) [Current prospects for development of materials for stabilizing interventions on the spine using spondylodesis (Review)]. Sovremennye Tekhnologii v Meditsine, 2018, vol. 10, no. 4, pp. 203-219. (in Russian)

4. Shao A., Ling Y., Xu L., Liu S., Fan C., Wang Z., Xu B., Wang C. Xenogeneic bone matrix immune risk assessment using GGTA1 knockout mice. Artif. Cells Nanomed. Biotechnol., 2018, vol. 46, no. sup3, pp. S359-S369. DOI: 10.1080/21691401.2018.1493489

5. Li J., Hara H., Wang Y., Esmon C., Cooper D.K.C., Iwase H. Evidence for the important role of inflammation in xenotransplantation. J. Inflamm. (Lond), 2019, vol. 16, pp. 10. DOI: 10.1186/s12950-019-0213-3

6. Luneva S.N., Nakoskin A.N., Kovinka M.A. Sposob polucheniia i konservatsii mineralizovannogo kostnogo matriksa [The way of obtaining and preserving mineralized bone matrix]. Patent RF no. 24955567, 2012. (in Russian)

7. SP 2.2.1.3218-14. Sanitarno-epidemiologicheskie trebovaniia $k$ ustroistvu, oborudovaniiu $i$ soderzhaniiu eksperimentalno-biologicheskikh klinik (vivariev) [Sanitary and epidemiological requirements for the arrangement, equipment and maintenance of experimental biological clinics (vivariums)]. (in Russian) Available at: http://docs.cntd.ru/document/420219460

8. GOST 33215-2014. Rukovodstvo po soderzhaniiu $i$ ukhodu za laboratornymi zhivotnymi. Pravila oborudovaniia pomeshchenii $i$ organizatsii protsedur [Guidelines for the maintenance and care of laboratory animals. Rules for equipping premises and organizing procedures]. (in Russian) Available at: http://docs.cntd.ru/document/1200127789

9. GOST 33216-2014. Rukovodstvo po soderzhaniiu i ukhodu za laboratornymi zhivotnymi. Pravila soderzhaniia i ukhoda za laboratornymi gryzunami $i$ krolikami [Guidelines for the maintenance and care of laboratory animals. Rules for the maintenance and care of laboratory rodents and rabbits]. (in Russian) Available at: http://docs.cntd.ru/document/1200127506

10. GOST R ISO 10993-1-2009. Natsionalnyi Standart Rossiiskoi Federatsii. Izdeliia meditsinskie. Otsenka biologicheskogo deistviia meditsinskikh izdelii. Chast 1. Otsenka i issledovaniia [The National Standard of the Russian Federation. Medical products. Part 1. Assessment and research]. Uutverzhden i vveden v deistvie Prikazom Rostekhregulirovaniia ot 06.08.2009 № 281-st [Approved and put in force by the Order of Rostekhregulirovanie of 06.08.2009 No. 281-st]. (in Russian) Available at: http://docs.cntd.ru/document/1200073860

11. Hetherington V.J., Kawalec J.S., Dockery D.S., Targoni O.S., Lehmann P.V., Nadler D. Immunologic testing of xeno-derived osteochondral grafts using peripheral blood mononuclear cells from healthy human donors. BMC Musculoskelet. Disord., 2005, vol. 6, pp. 36. DOI: 10.1186/1471-2474-6-36

12. Bernhardsson M., Dietrich-Zagonel F., Tätting L., Eliasson P., Aspenberg P. Depletion of cytotoxic (CD8+) T cells impairs implant fixation in rat cancellous bone. J. Orthop. Res., 2019, vol. 37, no. 4, pp. 805-811. DOI: 10.1002/jor.24246

13. Sun X., Liu C., Shi Y., Li C., Sun L., Hou L., Wang X. The assessment of xenogeneic bone immunotoxicity and risk management study. Biomed. Eng. Online, 2019, vol. 18, no. 1, pp. 108. DOI: 10.1186/s12938-019-0729-z

14. Croes M., Kruyt M.C., Loozen L., Kragten A.H., Yuan H., Dhert W.J., Öner F.C., Alblas J. Local induction of inflammation affects bone formation. Eur. Cell. Mater., 2017, vol. 33, pp. 211-226. DOI: 10.22203/eCM.v033a16

15. Lohmann C.H., Hameister R., Singh G. Allergies in orthopaedic and trauma surgery. Orthop. Traumatol. Surg. Res., 2017, vol. 103, no. 1S, pp. S75-S81. DOI: 10.1016/j.otsr.2016.06.021

16. Borregaard N. Neutrophils, from marrow to microbes. Immunity, 2010, vol. 33, no. 5, pp. 657-670. DOI: 10.1016/j.immuni.2010.11.011

17. Jasper A.E., McIver W.J., Sapey E., Walton G.M. Understanding the role of neutrophils in chronic inflammatory airway disease. F1000Res, 2019, vol. 8, F1000 Faculty Rev-557. DOI: 10.12688/f1000research.18411.1

18. Kuznetsova E.I., Chepeleva M.V., Chegurov O.K., Kliushin N.M., Sazonova N.V., Kaminskii A.V., Ermakov A.M., Ababkov Iu.V., Kamshilov B.V. Formirovanie neitrofilnykh vnekletochnykh lovushek u patsientov s osteoartrozom i iskhodom endoprotezirovaniia tazobedrennogo sustava [Formation of neutrophilic extracellular traps in patients with osteoarthrosis and the outcome of the hip arthroplasty]. Sibirskii Nauchnyi Meditsinskii Zhurnal, 2016, vol. 36, no. 6, pp. 60-64. (in Russian)

19. Diuriagina O.V., Kovinka M.A., Nakoskin A.N. Ksenoimplantatsiia matriksa kostnoi tkani pri zameshchenii defektov kosti u krolikov [Xenoimplantation of bone tissue matrix for bone defect filling in rabbits]. Veterinariia Kubani, 2016, no. 6, pp. 19-21. (in Russian)

Received: 03.06.2020

\section{Information about the authors:}

1. Olga V. Diuriagina, Ph.D. of Veterinary Sciences,

Ilizarov National Medical Research Centre for Traumatology and Orthopedics, Kurgan, Russian Federation, Email: diuriagina@mail.ru

2. Marina V. Chepeleva,

Ilizarov National Medical Research Centre for Traumatology and Orthopedics, Kurgan, Russian Federation,

Email: marina.barbara7@yandex.ru

3. Elena I. Kuznetsova,

Ilizarov National Medical Research Centre for Traumatology and Orthopedics, Kurgan, Russian Federation,

Email: citoz@mail.ru

4. Mikhail A. Kovinka, Ph.D. of Biological Sciences,

Ilizarov National Medical Research Centre for Traumatology and Orthopedics, Kurgan, Russian Federation

5. Alexander N. Nakoskin, Ph.D. of Biological Sciences,

Kurgan State University, Kurgan, Russian Federation 